ionosphere, in which researches he was largely responsible for the discovery of the magneto-ionic splitting of pulse radio echoes and the quantitative verification of ionospheric double refraction which had been predicted by a theory of mine. During July 1932-May 1933 he was a member of the British Radio Expedition to Tromsø, in North Norway, organized by the Royal Society as part of Britain's contribution to the work of the Second International Polar Year. It was this expedition which discovered the phenomenon of the polar radio 'black-out', associated with magnetic storm and auroral activity.

After obtaining the London degree of Ph.D., and becoming a Fellow of the Institute of Physics, Builder joined the Australian Radio Research Board in the latter part of 1933 . He then played an important part in developing the Board's new experimental techniques for ionospheric exploration and collaborated with the late A. L. Green in researches on the polarization of long radio waves and on the suppression of fading.

Towards the end of 1934 he joined Amalgamated Wireless (Australasia), Ltd., to take charge of its small group of research laboratories. Under his energetic and skilful direction this group developed rapidly until, at the time of his departure for the Army in 1941, it had grown into an effective organization with more than fifty members of staff. Many well-known Australian radio-physicists and engineers owe their selection and early professional training to the shrewd judgment and scientific and administrative capacity which he exercised during this period as chief of research.

While a major at Army Headquarters during part of the Second World War, Builder acted as adviser on radar, and later engaged in defence production as general manager of Airzone, Ltd. After the War he worked as a consultant and founded two electrical engineering companies. During part of this time he was able to give valuable assistance to the Department of Physics of the University of Sydney in coping with its excessive load of teaching. In 1949 he was appointed to the permanent staff of the Department as a senior lecturer and devoted himself largely to giving lectures on electricity and to the duties of the lecturer-incharge of second-year physics.

As a member of the Faculty of Science he was very active in proposing various reforms and successful in getting many of them adopted. In recent years he developed an interest in the theory of relativity and gave much time and thought to resolving the famous clock paradox of the special theory. These researches were carried out with his usual thoroughness and acumen and, although at times they brought him into conflict with well-known theoreticians, one of his last papers $^{1}$ appears to have settled the controversy by showing that "the clock paradox ... arose solely out of the elementary mistake of utilizing, in a single calculation, quantities expressed in the measures of two different reference systems". Such versatility and depth are not often found among the younger generation of physicists.

Builder's great interest in the welfare of his students, both collectively and individually, and his exceptional combination of technical, commercial and academic experience made him one of the most successful of teachers and a constant source of wise counsel to his academic colleagues.

EdWARD V. Appleton

1 Amer. J. Phys., 27, 656 (1959)

\section{Georges Claude}

Avec Georges Claude (décédé le 23 Mai) vient de dispareitre un des derniers pionniers, inventeurs. ingénieurs, savants, qui ont permis la révolution industrielle qui précéda la Première Guerre Mondiale. Ingénieur débutant, Georges Claud? s'intéresse à l'acétylène, rendu accessible par la fabrication au four électrique du carbure de calcium; en 1896, il crée l'industrie de l'acétylène dissous et permet l'essor de la soudure autogène, du découpage au chalumeau: les techniques de la consuruction mécanique sont immédiatement transformées.

Claude se préoccupe alors du prix de revient de l'oxygène, non pas tant pour abaisser le prix de la soudure au chalumeau que pour son application à la production des hautes températures. Avant la fin du siècle dernier, il envisage la possibilité de fabriquer le carbure de calcium dans un four à charbon soufflé à l'oxygène! Ses efforts sont couronnés de succès et la détente avec travail extérieur, qu'il industrialise dès 1902, est universellement utilisée. Fn 1910, il démontre dans les aciéries belges d'Ougrée la possibilité d'économies substantielles en sidérurgie par l'emploi de l'oxygène. Depuis la fin de la Deuxième Guerre Mondiale, ses prévisions ont été très largement justifiées ; l'avenir montrera, nous en sommes conveincus, que la production du carbure de calcium au four soufflé à l'oxygène n'était pas davantage une utopie.

Claude s'intéresse également aux gaz rares de l'air et réalise la production industrielle de l'argon, du néon, du krypton et du xénon. L'éclairage à incandescence s'en trouve transformé et ces travaux ont conduit à l'éclairage par fluorescence dont nous jouissons maintenant.

Au cours de la Première Guerre Mondiale, Georges Claude s'attaque dे la synthèse de l'ammoniaque; aux 250 atmosphères du Prof. F. Haber, il oppose audacieusement les 1,000 atmosphères auxquelles il prétend travailler, et il y réussit. Son procédé est encore employé et l'on peut dire que les procédés Casale ou Fauser ne sont qu'un compromis raisonnable entre les pressions déjà courantes du temps de Haber et les hyperpressions dont Claude a rendu possible I'emploi.

Du domaine des hyperpressions, son imagination créatrice entraine Georges Claude vers l'emploi des pressions réduites. Passionné des grands problèmes qui dominent l'avenir du monde, il voit là un moyen d'utiliser l'inépuisable réservoir d'énergie que constituent les océans par la différence de température entre les couches superficielles et les couches profondes de l'ęu. Dans une première installation, il réussit à entrainer une dynamo de $60 \mathrm{~kW}$. par une turbine mue par de la vapour à faible pression qui se condense au contact d'eau froide. La différence de température n'est que de $20^{\circ}$ C.; l'eau de la Meuse lui sert de source froide, et il prend comme source chaude cette même eau servan'́ à refroidir les tuyères du hautfourneau.

Georges Claude s'engage alors tout seul dans l'expérimentation industrielle. A Cuba, après trois centatives, il immerge dans le fond de l'océan un tube de deux mètres de diamètre et de plus de deux mille mètres de long. Il réussit à faire fonctionner son turbogénérateur et peut écleirer la station expérimentale qu'il a construite de ses deniers. Une nouvelle tentative pour atteindre une échelle industrielle $(2,000 \mathrm{~kW}$.) échoue par suite de l'hostilité des éléments, déchainés contre un inventeur génial. La 
fortune considérable gagnée par Georges Claude ne lui a pas permis de mener à bien, tout seul, l'audacieuse expérience de captation de l'énergie thermique des mers.

Le succès de l'opération Pluto durant la Deuxième Guerre Mondiale, les projets actuels de pipe-lines traversant la Méditerrannée sont le fruit do la tentative de l'inventeur français. Au moment où s'estompent les espoirs trop optimistes fondés sur la conquête rapide de l'énergì nucléaire à bon marché, on ne peut pas s'empêcher d'une certaine mélancolic en considérant qu'un effort beaucoup moins onéreux aurait pu réussir à nous mettre en possession d'uno énergie équivalente et ne présentant pas les mêmes dangers.

Avec le recul des années, l'oeuvre de Georges Claude prend tout son relief: il fut, dans toute l'acception du terme, un véritable créateur dont le génie inventif a généreusement servi son pays et la civilisation oxydentale.

\section{NEWS and VIEWS}

\section{Mathematics at Oxford:}

Dr. Graham Higman, F.R.S.

Dr. Graham Higman, who has recently been appointed to the Waynflete chair of pure mathematics in the University of Oxford, in succession to the late Prof. J. H. C. Whitehead, is a Balliol man who, apart from a brief sojourn in Cambridge, has divided his academic life between Oxford and Manchester. After the Second World War, he joined the mathematical staff of the University of Manchester as a founder member of the algebra school which has flourished there since that time. He remained in Manchester until 1955, when he accepted a readership in Oxford. As a pupil of J. H. C. Whitehead, he first worked on a problem of topological origin. In his hands it soon became algebraical, and in the rest of his career he has devoted himself entirely to the 'pure' theory of groups, especially infinite groups. To this theory he has made deep and influential contributions. Lately he has turned his attention to the border country of group-theory and logic, in which he has proved a theorem of great interest on the insolubility of certain group-theoretic problems. Dr. Higman was elected a Fellow of the Royal Society in 1958 .

Seismology in New Zealand: Dr. F. F. Evison

Dr. F. F. Evison has been appointed superintendent of the Seismological Observatory, Wellington, New Zealand (Department of Scientific and Industrial Research), in succession to Mr. R. C. Hayes (Nature, 187, 24; 1960). Dr. Evison was educated at West Christchurch High School and the Victoria University of Wellington, graduating in mathematics and physics. In 1947 he went to the Imperial College of Science and Technology, London, as a research student under Prof. J. McG. Bruckshaw, where he developed the technique of experimental seismology in which a transducer is used for generating seismic pulses in the ground. After returning to New Zealand in 1950 to join the Geophysical Survey, he brought this technique to bear on a variety of seismic propagation problems. He also mede $\varepsilon$ study of deformations of streta in coal-mines. In 1956 the Nuffield Foundrtion awarded Dr. Evison a Dominion Travelling Fellowship in the Natural Sciences, which took him for a yeer to the Department of Geodesy and Geophysies, Cembridge. Dr. Fvison and his colleagues produced the first geophysical evidence that the Antarctic ice-cap is underlain by a continental crust. They have recently extended the work, which depends on dispersive earthquake waves recorded in Antarctica, to obtain crustal thicknesses over the greater part of Antarctica and the surrounding oceans. The Seismological Observatory, Wellington, operates the Antarctic seismograph stations at Scott Base and Hallett, and also stations at Samoa and Raoul Island, es well as the network within New Zealand itself.

\section{The Russian Earth Satellite 1960入}

A SIGNIFICANT milestone on the road to space flight was passed on August 20, when, for the first time, living animals were successfully brought back to earth after being in orbit in space, aboard the second Russian space-ship satellite. This satellite, which weighed 4,600 kgm., was launched at about $08 \mathrm{~h} .45 \mathrm{~m}$. U.T. on August 19, and entered a nearly circular orbit, inclined at an angle of $65.0^{\circ}$ to the equator. Its height, varied between $306 \mathrm{~km}$. at perigee and $340 \mathrm{~km}$. at apogee, and the period of revolution was $90.7 \mathrm{~min}$. The satellite, also known as Sputnik 5, was designated $1960 \lambda 1$, and was accompanied in orbit by its finalstage rocket $(1960 \lambda 2)$. The living creatures in the satellite included two dogs, 40 mice $(21$ black and 19 white) and 2 rats ; there were 15 phials containing Drosophila and 12 with the alga Chlorella; seeds of maize and many other plants, cancerous cells, and a variety of micro-organisms. The satellite also carried a radio transmitter having a frequency of 19.995 Mc./s., and instruments for measuring the composition of cosmic rays and the intensity of solar X-ray and ultra-violet radiation. It is stated that the pulse and rate of respiration of the dogs were measured and their behaviour observed by television, the information being stored and telemetered back to earth. On the eighteenth revolution of the satellite its velocity was reduced by a retro-rocket and it descended through the atmosphere; all the animals and biological specimens are reported as being recovered in good condition.

\section{Research and Development in Industry}

DR. E. J. SolvaY's presidential address to the Society of Chemical Industry at Bristol on July 5 reviews the evolution of the chemical industry, and more particularly the part which research has played in the development of the industry. He also stressed the need for more men in scientific research and for the more effective use of such highly trained manpower (Chem. and Indust., 976; July 30). Urging a real co-ordination of research programmes on an international scale as the result of agreement freely negotiated between companies interested in the same activities, Dr. Solvay was thus endorsing a plea which Viscount Chandos had made earlier in the vear to 